\title{
Conservative transformation: actively managed corporate volunteerism in Hong Kong
}

\author{
Robin Stanley Snell • Amy Lai Yu Wong
}

Received: 7 April 2011 /Accepted: 11 September 2011 /Published online: 6 October 2011

(C) Springer Science+Business Media B.V. 2011

\begin{abstract}
Our Hong Kong-based study used interviews with volunteers and other stakeholders to investigate the perceived integrity and commitment of firms' adoption of actively managed corporate volunteerism (AMCV), to examine whether AMCV was removing barriers against voluntary community service work and to identify volunteers' motives for AMCV involvement. Interviewees perceived that firms were adopting strategically instrumental approaches to AMCV, combining community service provision with corporate image promotion and/or with organisational development. They indicated that although AMCV was mobilizing people, who would not otherwise have chosen to volunteer, instances of 'conscription' were uncommon. Those who had served as volunteers described positive motives for their own involvement, such as altruism, principlism, self-development, loyalty to the firm and relationship building with colleagues and service recipients. Some expressed that volunteering had been a highly rewarding self-transformation experience. Our study also used the career orientations inventory (COI) to examine career anchors. COI scores indicated that non-governmental organisation (NGO)-based employees and some firm-based paid AMCV organisers preferred the service/dedication to a cause anchor and that firm-based unpaid organisers-cum-participants preferred the lifestyle anchor. Volunteers without organiser roles had miscellaneous preferences but leaned toward the security anchor. From our findings, we argue that it would benefit all parties if firms, in close collaboration with NGOs, were to expand the range of volunteering opportunities that are available to employees and help them to choose activities and roles that are congruent with their career anchors, if they so wish.
\end{abstract}

R. S. Snell ( $\bowtie)$

Department of Management, Lingnan University, 8, Castle Peak Road, Tuen Mun, New Territories, Hong Kong SAR, China

e-mail: robin@Ln.edu.hk

\section{A. L. Y. Wong}

Department of Management \& Marketing, Faculty of Business, Hong Kong Polytechnic University, Kowloon, Hong Kong SAR, China

e-mail: AmyLY.Wong@inet.polyu.edu.hk 
Keywords Career anchors - Corporate social responsibility - Corporate volunteerism .

Altruism

\section{Introduction}

Actively managed corporate volunteerism (AMCV) is an expression of philanthropy, in which a firm endorses an ongoing programme of community service activities and provides a platform for their employees, and in some cases family members, to join in as volunteers. Some firms may employ one or more employees to coordinate the associated activities as part of their formal, paid, job duties (Shin and Kleiner 2003), typically in collaboration with non-governmental organisations (NGOs). Firms receive no fees for operating such platforms, and volunteers are unpaid, although they may receive prizes or certificates for their contributions. While Peloza and Hassay (2006) have characterised this arrangement as intra-organisational corporate volunteerism, we prefer the term AMCV because it typically involves interorganisational collaboration between firms and NGOs.

In this paper, we examine two issues that prior research has not examined: perceptions about firms' integrity and community service commitment in adopting $\mathrm{AMCV}$ and the relationship between the career anchors of individual employees and their mode of involvement in AMCV. We also investigate how AMCV has been inducing and motivating employee involvement in community service work, issues that have not been studied before in Hong Kong.

In the USA, while AMCV dates back to the early 1970s or before (Burke et al. 1986), it has gained momentum and popularity in the last two decades (Post et al. 2002; Houghton et al. 2009). Elsewhere, AMCV has taken root in other Anglo-Saxon countries such as in the UK, where it has been championed by Business in the Community, a business-run charity (Anonymous 2004; Quirk 1998), and in Australia (Cavallaro 2007). It has also developed a global presence (Global Corporate Volunteer Council 2011).

While AMCV has been more strongly institutionalized in the USA than in Asia (McAlister and Ferrell 2002; Yotsumoto 2002, 2010), governments around the world have been encouraging firms to partner with NGOs to source volunteers via AMCV for community service work (Bates and Kim 2008; Loza 2004; Mantel et al. 2007; Yamamoto 1999). Hong Kong, the location of the current study, is no exception. In Hong Kong, AMCV gained momentum after the introduction in 2002 of the Caring Company Scheme, sponsored by the Hong Kong SAR government and organised by the Hong Kong Council of Social Service (HKCSS), an association representing over 300 NGOs. Before the advent of the Caring Company Scheme, corporate volunteerism in Hong Kong tended to reflect grassroots activism, with staff of some large firms providing voluntary services outside working hours on a largely spontaneous and informal basis.

Research objectives

Our research had three sets of objectives. First, we examined the perceived integrity and commitment of firms' adoption of AMCV in Hong Kong. Firms typically 
leverage AMCV as a public relations tool. For example, while undertaking community service work, employees may wear T-shirts, hats or badges that bear their company's name and logo (Bory 2007; Peloza and Hassay 2006). Furthermore, many Hong Kong firms display the Caring Company logo, awarded for engagement in AMCV and other aspects of corporate social responsibility (CSR), on their websites. One of our concerns was the risk that AMCV might become overcommercialised, deflecting effort towards corporate image building, diluting the provision of substantive community service work and detracting from the building of cooperative relationships with partner NGOs. Another concern was that some socalled volunteers might feel that they have been conscripted. Therefore, we examined whether Hong Kong firms were perceived as duly balancing and circumscribing the commercial aspects of AMCV with sincere and authentic commitment to the provision of valuable services to the community in cooperation with NGOs and with genuine concern to respect employees' right to choose whether or not to participate.

Prior research has indicated that there are considerable barriers against undertaking voluntary work in Hong Kong. Although Hong Kong citizens believe that firms should contribute to the community (Ramasamy and Yeung 2009), typically they are not proactive in this process (Sing 2009). Very few Hong Kong residents regard contributing to the community as an important life attribute (Sing 2009). There is no established tradition of helping the poor, vulnerable and needy in society (Wong 2008, p. 332) and materialistic values predominate (Wong and Wan 2009). Furthermore, compared with other locations, leisure time is relatively scarce in Hong Kong (UBS 2009), constituting another barrier to volunteering (Quirk 1998). Our second set of research objectives sought to establish whether AMCV platforms were removing barriers of this kind, to mobilize employees to undertake community service work though AMCV, and sought also to identify and analyse volunteers' motives for involvement, along with the personal benefits that they were deriving from their involvement.

Our third set of research objectives sought to examine the relationship between career anchors (Schein 1978, 1993) and employees' mode of involvement in AMCV. From the perspective of human capital development, it is desirable for participants in AMCV to derive career value from the actual work that they undertake while volunteering (Bang and Ross 2009; Clary et al. 1998) and for NGOs to use volunteers as sources of specialist expertise (Global Corporate Volunteer Council 2011; Loza 2004). However, such considerations may be overshadowed by the philosophy that 'every little helps'. Typical generic AMCV activities, such as raising funds through retail sales, accompanying disabled people to the theatre, driving or gardening (Global Corporate Volunteer Council 2011), may match a limited range of career anchors among the volunteers. We sought to identify some missed opportunities for engaging the full range of diverse talents and vocational values among participants in AMCV. In the next three sections, we shall explain the analytical frameworks and research questions that we derived from reviewing the respective literatures for the three sets of research objectives. 


\section{The integrity and commitment of firms' adoption of AMCV}

Literature review and analytical framework

Strategic approaches to corporate volunteerism vary from firm to firm (Global Corporate Volunteer Council 2011). For our first set of research objectives, about the perceived integrity and commitment entailed by firms' strategic approaches to AMCV, our analytical framework distinguishes between opportunistic, strategically instrumental and altruistic approaches and contrasts them all with informal approaches to corporate volunteerism.

\section{Opportunistic approaches}

Parsons (2004) writes:

One of the most problematic aspects of organizational ethics programmes and the public relations opportunities they present is the danger of making these ethics programmes nothing more than window dressing, where management pays lip service to ethics and PR capitalizes on it, spinning it into something it really isn’t (p. 158).

Just as firms can engage in window dressing and façade (Sims and Brinkmann 2003, p. 243) to fabricate commitment to other aspects of CSR (Norman and MacDonald 2004), firms with an opportunistic approach to AMCV would lack genuine commitment to community service. Signs of opportunistic approaches to AMCV might include heavy usage of marketing tools without substantive contributions (Sims and Brinkmann 2003); reluctance to commit resources, for example, not employing paid organisers; having only nominal relationships with NGOs (Jamali and Keshishian 2009) and enlisting volunteers through conscription, i.e. recruiting them under heavy pressure (Powers, 1998; Teague 2008). Such approaches might eventually backfire and diminish a firm's reputation (Quirk 1998).

\section{Strategically instrumental approaches}

Firms with a strategically instrumental approach to AMCV aim to provide valuable community service while seeking corresponding returns in terms of social, political and reputational capital. They embrace a 'business model' (Global Corporate Volunteer Council 2011), which assumes that AMCV activities need to be consistent with commercial interests by adding value to the company (Von Tunzelmann and Cullwick 1996). This approach may be the most common one among firms:

Corporate volunteering always has been done for some kind of strategic reason. It has evolved from its original value in community relations to use as a tool in management of corporate culture, employee engagement, brand management, external relations and entry into new markets (Global Corporate Volunteer Council 2011). 
In managing $\mathrm{AMCV}$, firms with this kind of approach guard against subordinating commercial interests to community service provision and seek to strike a balance between deriving value for the firm, generating benefits for the community and satisfying participating employees. They regard AMCV as a discretionary investment in goodwill that could be curtailed if the payoffs for the firm are deemed to be insufficient, rather than as a moral obligation (Carroll 1979, 1991).

Signs of a strategically instrumental approach to AMCV might include the following. The firm might employ one or more paid AMCV organiser(s) to help to build the firm's reputation through AMCV-related public relations and social marketing work (Loza 2004; Waddell 2000). Such personnel might also work to improve intra-firm solidarity and cooperation through AMCV-related organisational development activities (Goffee and Jones 1998; Peloza and Hassay 2006). Paid organisers in firms with this approach would tend not to assume responsibility for community development or social work because partnering NGOs would be expected to provide leadership within these domains. In the early stages of adoption of AMCV, firms with a strategically instrumental approach would typically regard NGOs as channels for employees to engage in relatively high-profile AMCV activities, rather than as clients for less conspicuous background support services (Jamali and Keshishian 2009). While not pressurizing employees to volunteer (Powers, 1998), managements would look favourably upon volunteering as an expression of organisational citizenship behaviour. Accordingly, if managements were to believe that volunteering contributes to good public relations, they would regard it is a kind of loyal boosterism (Moorman and Blakely 1995; Peloza and Hassay 2006), and if they were to believe that volunteering contributes to organisational development, they would regard it as a kind of pro-social teammindedness (Dovidio et al. 2006; Pearce and Herbik 2004).

Strategically instrumental approaches to AMCV might entail some adaptation and adjustment of the ideas of Milton Friedman (1912-2006). Friedman (1970) argued that deploying firm resources to serve the community would only be justified if this contributes to the maximization of stockholders' economic returns. Business leaders in Hong Kong tend to hold Friedmanite beliefs (Gill and Leinbach 1983; Tsoi 2010), yet many also support the Caring Company Scheme. This juxtaposition of moral sentiments may reflect an 'enlightened' orientation towards profit maximizationrecognition that Hong Kong consumers have come to expect firms to be responsive to community needs (Ramasamy and Yeung 2009) and that firms might suffer some reputational damage and reduced economic returns, if they fall short of contemporary expectations about the relationship between business and society (Saiia et al. 2003). Strategically instrumental approaches to AMCV are nonetheless open to the criticism that, in evaluating actual or proposed AMCV programmes against estimated public relations impact and economic costs and returns, they are ultimately calculative, lack deep moral commitment and prioritise stockholder interests over actual community needs (Brown 1997).

\section{Altruistic approaches}

Altruistic approaches to AMCV would assign a low priority to the need to derive commercial payoffs from the related activities. Firms with such an approach would 
regard AMCV as a moral obligation (Carroll 1979), reflecting the need to reciprocate for infrastructure provided by society, to compensate for burdens imposed on society or to express the norm of beneficence in helping the less fortunate in society (Gouldner 1973). Altruistic approaches to AMCV would embrace a social service or human development model, focusing on helping and empowering people in need and on developing committed volunteers (Global Corporate Volunteer Council 2011). Cavallaro (2007) found evidence of this approach among some Australian firms.

Firms with an altruistic approach would soft-pedal the linkages between AMCV and public relations, and although they might consider AMCV beneficial for intrafirm solidarity, the main driver would be to meet community needs. Accordingly, paid AMCV organisers in such firms would be externally facing, committed to providing services of value to the community and to making a difference to service recipients (Global Corporate Volunteer Council 2011). Reflecting humanitarian values and societal awareness (Coupland 2006; Owen et al. 2000), firms with an altruistic approach would likely encourage their employees to participate in AMCV, but without coercing them to do so (Bates and Kim 2008; Lantos 2001), and would praise them for taking part. They would also attempt to develop integrative or 'deep' partnering arrangements with NGOs, in order to increase the long-term community impact of AMCV activities (Austin 2000; Jamali and Keshishian 2009), and to this end they would seek to address the capacity-building needs of partner NGOs (Loza 2004).

Underpinning altruistic approaches to AMCV is the belief that firms have a multifiduciary duty of fairness and care towards various stakeholder groups that can, if necessary, override shareholders' interests (Banerjee 2007; Freeman 1984, 1994; French 1979; Gibson 1990; Reed 1999). This may be expressed as the view that 'business has a social responsibility beyond making a profit' (Singhapakdi et al. 1996). In the context of contemporary expectations about business and society, an altruistic approach might entail committing resources to AMCV that exceed the level needed to sustain the firm's reputation.

\section{Informal approaches}

Firms with an informal approach to volunteerism would not actively manage it and would not have a centrally determined strategy for it. They would not employ paid AMCV organisers and would not commit other resources to volunteerism. They would, by default, devolve decision making about volunteerism to informal networks of employees at the 'grassroots', with relatively low expectations of deriving commercial payoffs. The Caring Company Scheme has encouraged Hong Kong firms to move away from informal approaches to volunteerism. For example, the scheme requires firms to have formal systems to disseminate information about volunteering opportunities, to provide volunteer training, to arrange venues for volunteering work, to keep records about and recognize employee involvement in AMCV and to provide financial and in-kind resources to support volunteering efforts. To the extent that a firm operates such systems, it is no longer adopting an informal approach to volunteerism. 


\section{Comparing the four approaches}

Our above conceptual analysis implies that altruistic approaches to AMCV reflect relatively greater commitment to community service than do strategically instrumental approaches, which in turn entail greater commitment to community service than opportunistic and informal approaches. It also follows that both altruistic and strategically instrumental approaches entail relatively high levels of firm integrity in adopting and operating AMCV, while opportunistic approaches entail relatively low levels of firm integrity. Questions about integrity in embracing volunteerism may not apply to firms that adopt informal approaches to corporate volunteerism, since in such cases the volunteering activities are not actively managed by the firm. Table 1 summarizes the four theorized approaches.

Research questions about firm integrity and commitment in adopting AMCV

We developed nine research questions about the perceived integrity and commitment of Hong Kong firms in relation to AMCV. These questions were open-ended and did not presuppose, for example, that particular strategic approaches to AMCV would necessarily entail particular levels of commitment or integrity. The research questions are as follows: As perceived by (a) firm-based AMCV participants and (b) employees at partner NGOs:

RQ1. What is the prevailing strategic approach that firms have been adopting for AMCV?

RQ2. What signs are there, if any, of a lack of commitment by firms to community service?

RQ3. What signs are there, if any, of a lack of integrity by firms in operating AMCV?

RQ4. What are the main roles of paid AMCV organisers in firms?

RQ5. What corporate payoffs do firms seek from AMCV?

RQ6. What are the actual payoffs for firms from AMCV?

RQ7. What are the main societal benefits of AMCV?

RQ8. What characterises the working relationships that firms develop with NGOs?

RQ9. To what extent is participation in AMCV by employees genuinely voluntary?

\section{Establishing motives for employee volunteering}

Our second set of research objectives sought to establish whether AMCV was removing barriers to volunteering and to identify what the motives and payoffs were for participating employees. Quirk (1998, p. 18) identified some barriers to volunteering at the level of the individual employee: lack of awareness of suitable opportunities, reluctance to engage in volunteering without the support of friends or colleagues, feeling that one's efforts would not make much of a difference and waiting passively to be invited. Peloza and Hassay (2006) found that AMCV programmes in the USA overcame such barriers by legitimizing NGOs, by providing a convenient channel for volunteering and by enhancing potential volunteers' 


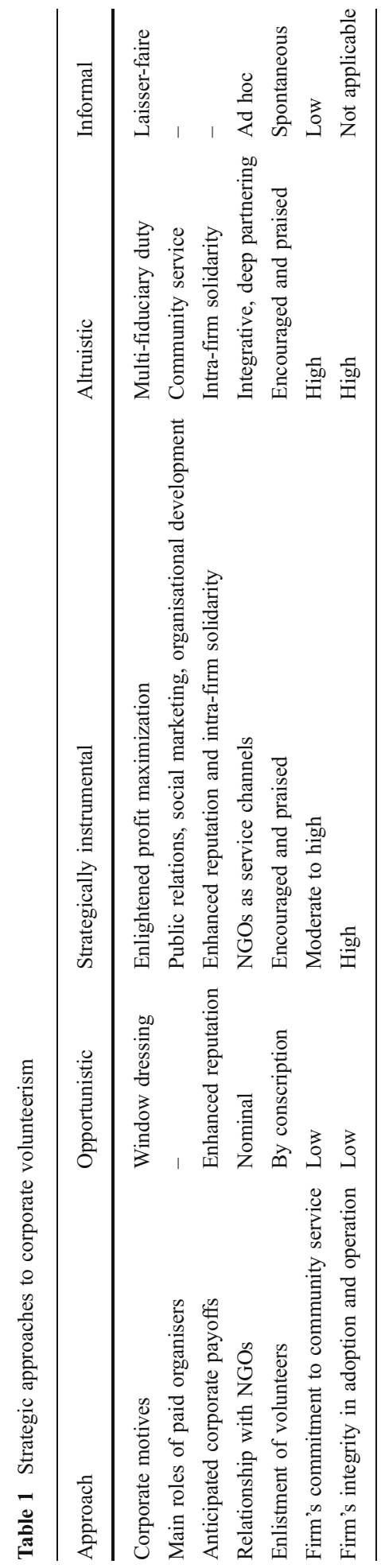


awareness of community needs. Extrapolating from UK findings (Lynn and Davis Smith 1995) to the case of New Zealand, Quirk (1998, p. 18) surmised that there was a large pool of latent volunteers, who would participate in AMCV, if they were given appropriate opportunities and encouragement.

Hong Kong's Caring Company Scheme provides infrastructure to help firms identify suitable NGOs and build partnerships with them and gives guidance to firms on how to engage employees as volunteers. However, for individual employees, lack of discretionary time (UBSS 2009) and unsupportive wider cultural norms (Lau 1982; Ralston et al. 1993; Redding 1990; Westwood and Posner 1997) constitute major barriers to volunteering in Hong Kong. We wondered whether, and how, firms were overcoming such barriers to enlist participation in AMCV by those employees, who had had no prior involvement in volunteering, or by those whose prior community service volunteering experience had been in the distant past and whose interest in volunteering had become dormant. We investigated whether firms were merely inducing employees, who had already been engaging in volunteering through other channels unrelated to the firm, to switch to volunteering through AMCV. Hence, the following research question:

RQ10. To what extent does AMCV provide a bridge to enlist those employees, who would otherwise not undertake volunteer work?

We also sought to identify the individual-level motives that were driving employees' involvement in AMCV. Prior studies have identified a mixture of intrinsic and extrinsic motives for volunteering (Metzer 1996, 2003). An established typology distinguishes four ultimate goals for people's engagement in pro-social activities (Batson 1994; Batson et al. 2008; Grant and Berg 2010), such as volunteer work. The first goal is altruism, defined as simple desire to support others' wellbeing, irrespective of personal benefit (Hoffman 1978; Haski-Leventhal 2009). The second goal is egoism, which includes the desire to experience positive emotions and reduce negative emotions, to gain material rewards and avoid punishments, to develop higher self-esteem or to benefit from personal development. The third goal is principlism, which is defined as the desire to uphold or advance an ethical cause or a moral principle. The fourth goal is collectivism, i.e. the felt need to defend or strengthen one's bond or relationship with a particular group (Batson 1987; Grant and Berry 2011). For example, volunteers may appreciate the opportunity to build relationships with service recipients (Frisch and Gerrard 1981; Morrow-Howell and Mui 1989; Wiggins 1991). An alternative typology of 'motivation functions' (Clary et al. 1998) broadly matches the above typology, but in addition identifies a fifth goal of volunteering, that of understanding, i.e., taking opportunities for new learning experiences and/or for utilizing knowledge or skills that would otherwise not be practiced.

A prior USA-based study (Peloza and Hassay 2006) found that employees' engagement in AMCV was driven by various combinations of goals. In that study, the volunteers gained a sense of task significance when they witnessed their compassion being appreciated and when they discovered that they were making a positive difference to others' lives (Frost et al. 2006; Grant 2008). Such experiences not only met the goal of altruism but also induced 'warm glow' feelings (Andreoni 1990), which met the goal of egoism. 
Many participants in the Peloza and Hassay (2006) study were found also to have had political motives for engaging in AMCV, through which they had sought recognition from their senior managers, in the hope of longer-term career progression. Employees in the Peloza and Hassay (2006) study tended to feel that they had gained such recognition and thereby met the goal of egoism. They also tended, through AMCV, to develop a strong sense of identity with and pride in their firm by serving as its ambassadors, thereby meeting the goal of collectivism. Teague (2008) similarly found that American volunteers were motivated by a combination of collectivism and egoism, namely the opportunity to cooperate in undertaking AMCV with close acquaintances or friends, whose company they enjoyed.

Also in the Peloza and Hassay (2006) study, those employees, who assumed responsibility for recruiting colleagues to join AMCV activities, met the goal of principlism by furthering causes that they personally valued, while also meeting the goal of collectivism by building closer ties with members of their immediate work group and circles of friends. On the basis of these prior studies, we anticipated that there would be plurality of motives for engagement in AMCV, and our associated research question was:

RQ11. What are the motives for ongoing involvement in AMCV among volunteers?

\section{Career anchors and mode of individual involvement in AMCV}

Our third set of research objectives sought to identify relationships between career anchors, which we considered to be patterns of self-perceived talents, motives and values that guide, constrain, stabilize and integrate an employee's subjective career (Schein 1978) and four types of AMCV-related role. The people occupying such roles fell into four categories in our study. The first category comprised employees within NGOs, whose jobs involved liaison with firms and their volunteers (for short, NGO-based respondents). The second category comprised employees within firms, whose jobs involved organising AMCV activities for volunteers from those firms (for short, firm-based paid AMCV organisers). The third category comprised those employees within firms, who voluntarily organised and took part in AMCV activities on an unpaid, basis (for short, firm-based, voluntary AMCV organisers-cumparticipants). The fourth category comprised those employees within firms, who simply participated in AMCV activities as volunteers (for short, voluntary AMCV participants without organiser roles).

Schein (1993) identified eight career anchors, namely technical and functional competence (TF), general managerial competence (GM), autonomy/independence (AU), security/stability (SE), entrepreneurial creativity (EC), service/dedication to a cause (SV), pure challenge $(\mathrm{CH})$ and life style (LS). Employees normally become attached to one principal career anchor, which is characterised by valued attributes that they would not abandon. These attributes are, respectively, applying and continuously developing discipline-based skill (TF), opportunity to manage others across an organisation for results (GM), enduring freedom to control one's own activities (AU), financial or job security (SE), creating one's own enterprise based on personal endeavour (EC), achieving something of benefit or value to others (SV), 
seeking to achieve the almost impossible $(\mathrm{CH})$ and harmony between personal, family and work positions (LS).

It is generally assumed that meaningful life and occupational experience is required before a principal career anchor becomes established and that changes in preference for a principal career anchor are temporary (Arnold et al. 1998; Perren and Morland 1999; Schein 1996). Employees with congruence between their principal career anchor and salient aspects of their objective career report higher job satisfaction (Danziger and Valency 2006). The SV career anchor, given its pro-social orientation, was of special interest in this study. We cite below two detailed definitions of SV as a principal career anchor:

What you would not give up is the opportunity to pursue work that achieves something of value, such as making the world a better place to live; solving environmental problems; improving harmony among people; helping others; improving people's safety; curing diseases through new products (Schein 1993).

Individuals anchored in SV need to feel that their work is making a contribution to society and has meaning. They value fairness and ethics and want their community values to be matched by the values and policies of their organisation. If these values are matched they are likely to exhibit a high level of passion for their work and loyalty to their organisation. (Steele 2009, p. 65)

Schein (1993) found that the incidence of the SV career anchor in his studies was just over 5\%, but he predicted that this proportion would increase (Schein 1996). In line with this prediction, strong preference for SV was later found among UK-based managers (Kniveton 2004) and among overseas development volunteers from New Zealand (Hudson and Inkson 2006). However, only moderate preference for SV was found among Taiwanese managers (Wong 2007), and low preference for SV was found in Israel (Danziger and Valency 2006).

Altruism and/or principlism as motives for involvement in AMCV do not necessarily reflect the SV career anchor. Volunteers with such motives might still prefer to occupy paid jobs that match other career anchors. Nonetheless, given the social work orientation of Hong Kong NGOs (Yim 2008), we expected that the NGO-based respondents in our study would have SV as their principal career anchor. We also expected that the firm-based paid AMCV organisers in our study would tend to have SV as their principal career anchor, reflecting that they had full-time jobs that were oriented to pro-social goals (Hemingway and Maclagan 2004). We expected that among firm-based, voluntary AMCV organisers-cum-participants and among voluntary AMCV participants without organiser roles, there would be a diversity of principal career anchors, including SV [expressing altruism 'on the wing' (Wong 2002)], SE (belonging and security needs), LS (work-life balance needs) and TF (application of specialist competences to AMCV work). Our related research questions were [among (a) employees at partner NGOs; (b) firm-based, paid AMCV organisers; (c) firm-based, unpaid, AMCV organisers-cum-participants and (d) firmbased AMCV participants without organiser roles]:

RQ12. What is the relative incidence of the SV career anchor?

RQ13. What career anchors other than SV are prominent? 


\section{Methodology}

Sample specification and data collection

We adopted a key informant strategy for data collection (Chen et al. 1993; Gilchrist 1992; Kumar et al. 1993). Invitation letters were sent to large firms and to HKCSS. These indicated our areas of interest and stated that the research was for academic purposes only and that personal data would not be revealed.

The letters were followed up by telephone calls to 30 potential respondents, who were all Hong Kong Chinese. These calls resulted in 27 eventual respondents. Among these, three (two females, one male) were employees of NGOs (different ones). All three had paid roles involving liaison with firms providing volunteers through AMCV. The other 24 respondents (11 females, 13 males) were from 10 industrial/commercial firms. Among these respondents, five had jobs that included organising AMCV-related events and activities; another six were actively involved in organising as well as participating in AMCV events and activities but such involvement was entirely voluntary and unpaid. The remaining 13 respondents had served as unpaid volunteers in AMCV activities but had taken no active part in the formal organisation and/or formal promotion thereof.

Job titles among our interviewees ranged, in terms of seniority of rank, from senior manager/director (nine people), through middle manager (11) to junior manager/clerk (seven). The highest qualifications ranged from HKCEE ' $\mathrm{O}$ ' level to doctorate, while the age distribution was 30-34 (7), 35-39 (6), 40-44 (3), 45-49 (5), 50-54 (3) and 55-59 (3). As many as 44\% of the interviewees identified themselves as Catholics or other Christians, as compared with $14 \%$ among the general Hong Kong adult population (Sing 2009). No other kinds of religious belief were declared. Respondents with religious affiliations were distributed fairly evenly in our sample across: NGO-based employees; firm-based, paid AMCV organisers; firm-based, unpaid, voluntary AMCV organisers-cum-participants and firm-based, voluntary AMCV participants without organiser roles.

Table 2 lists the age, sex and type of AMCV employment of each respondent and assigns each respondent a code that is used in the findings section to tag interviewees' quotes. For firm-based respondents, codes begin with letters A to J to distinguish the firms for which they worked. For example, AFUO1 and AMUO1 both worked for firm A. The NGO-based respondents, each with different employers, are distinguished from firm-based employees through codes that begin with $\mathrm{N}$. The second letter of each code is either F or M, denoting female or male. Among firm-based respondents, the remaining alphabetical digits of each code refer to different AMCV-related roles, with PO denoting paid organisers, UO denoting unpaid organiser-cum-volunteers and $\mathrm{V}$ denoting unpaid volunteers without an organiser role. The last digit (numerical) of each code distinguishes between particular individuals, who were employed by the same firm, who were of the same gender and who had the same AMCV-related role, for example, IFV1 and IFV2.

We drew on both individual-level and organisational-level perspectives to address our research questions, and we combined a qualitative approach for identifying perceptions and espoused motives, with the use of a paper and pencil self-diagnostic instrument that yielded simple numerical scores on career anchors. Researchers have 
Table 2 Respondents

\begin{tabular}{|c|c|c|c|}
\hline Code & Sex & Age & Type of AMCV role/job title \\
\hline AFUO1 & $\mathrm{F}$ & $30-40$ & Unpaid volunteer organiser-cum-participant, firm A \\
\hline AMUO1 & M & 35 & Unpaid volunteer organiser-cum-participant, firm A \\
\hline AMUO2 & M & 31 & Unpaid volunteer organiser-cum-participant, firm A \\
\hline BMPO1 & M & 46 & Paid organiser (assistant manager, quality assurance, environmental), firm B \\
\hline CMUO1 & $\mathrm{M}$ & 45 & Unpaid volunteer organiser-cum-participant, firm C \\
\hline CMUO2 & M & $50-55$ & Unpaid volunteer organiser-cum-participant, firm C \\
\hline DFPO1 & $\mathrm{F}$ & 34 & Paid organiser (senior public relations manager), firm D \\
\hline EFPO1 & $\mathrm{F}$ & 37 & Paid organiser (senior manager, corporate communication), firm E \\
\hline FFV1 & $\mathrm{F}$ & 32 & Volunteer participant without organiser role, firm $\mathrm{F}$ \\
\hline FMPO1 & M & 43 & Paid organiser (public relations director), firm F \\
\hline FMV1 & M & 40 & Volunteer participant without organiser role, firm $\mathrm{F}$ \\
\hline GFV1 & $\mathrm{F}$ & $40+$ & Volunteer participant without organiser role, firm $\mathrm{G}$ \\
\hline HFV1 & $\mathrm{F}$ & $35+$ & Volunteer participant without organiser role, firm $\mathrm{H}$ \\
\hline HFV2 & $\mathrm{F}$ & $30+$ & Volunteer participant without organiser role, firm $\mathrm{H}$ \\
\hline HMUO1 & M & 45 & Unpaid volunteer organiser-cum-participant, firm H \\
\hline HMV1 & $\mathrm{M}$ & 31 & Volunteer participant without organiser role, firm $\mathrm{H}$ \\
\hline HMV2 & M & 56 & Volunteer participant without organiser role, firm $\mathrm{H}$ \\
\hline IFV1 & $\mathrm{F}$ & $40-50$ & Volunteer participant without organiser role, firm I \\
\hline IFV2 & $\mathrm{F}$ & 34 & Volunteer participant without organiser role, firm I \\
\hline IFV3 & $\mathrm{F}$ & 56 & Volunteer participant without organiser role, firm I \\
\hline IMV1 & M & 53 & Volunteer participant without organiser role, firm I \\
\hline IMV2 & M & 55 & Volunteer participant without organiser role, firm I \\
\hline JFPO1 & $\mathrm{F}$ & 31 & Paid organiser (senior corporate communication mgr), firm $\mathrm{J}$ \\
\hline JMV1 & M & 50 & Volunteer participant without organiser role, firm J \\
\hline NF1 & $\mathrm{F}$ & $35-40$ & Social worker-unit in-charge (education and development), NGO1 \\
\hline NF2 & $\mathrm{F}$ & 37 & Centre-in-charge, NGO2 \\
\hline NM1 & M & $45+$ & Vice-Chair/Director, NGO3 \\
\hline
\end{tabular}

argued that 15-30 diverse respondents are sufficient to develop robust findings that are based on qualitative research (Marshall 1996; Miles and Huberman 1994; Sandberg 1994, p. 72). We judged that given the mixed methods used in our study, 27 respondents from diverse organisations and with diverse modes of involvement in AMCV would generate a body of data that would be sufficiently rich to support in-depth analysis.

Individual, semi-structured interviews were conducted with all our respondents in Cantonese, in respondents' offices, guided by a checklist of open-ended questions, and drawing upon the critical incident technique (Chell, 1999; Flanagan 1954). These interviews lasted about one and a half hours each, and with the consent of the respondents, each was tape-recorded.

For RQ12 and RQ13, we combined open-ended interview questions about career interests with the administration of two items that had been emailed to each respondent prior to the interview. The first item was a Chinese version of the 40 -item 
Career Orientation Inventory (COI) (Schein 1993). The second item was a biographical data sheet, used to identify age, gender, qualifications, religion and working experience.

Prior research with the corresponding English version of the COI has established construct validity for all eight career anchor subscales, except EC, for which separate entrepreneurial and creativity components have been identified (Danziger et al. 2008). Since EC was not of primary interest in our study, we regarded the COI as sufficient for our purposes. Part of each interview involved checking the written responses to the $\mathrm{COI}$ and asking further questions to verify preferences among the career anchors, in particular, the salience to interviewees of the SV anchor. For example, firm-based employees were asked: "Was AMCV a factor in your choice to work for this company?', while NGO-based interviewees were asked: 'Why did you choose to work in an NGO?' and 'What do you see as the contributions that an NGO can make to society?'. Respondents with COI scores that were high on SV were asked to explain how they had acquired or developed the associated pro-social values. All respondents were asked to describe their likely future career path and to explain whether this might involve employment as organisers of AMCV, or within the wider field of CSR.

There were some additional interview questions. For example, in addressing RQ1, RQ5 and RQ6, firm-based respondents were asked, 'What do you see as the main value for your company in sponsoring CSR?', and for RQ11, they were asked, 'What were the main reasons why you chose to volunteer for, or allowed yourself to get involved in your current or most recent AMCV programme or activity?'. At the end of each interview, interviewees were given a small token of appreciation. To supplement interview data, websites of host firms were examined for content about AMCV.

\section{Data analysis}

For the qualitative analyses, selective coding (Strauss and Corbin 1990) was adopted at the outset. Data were coded, categorized and clustered in emergent patterns that were relevant to the research questions. Subsequently, using the constant comparison method (Goetz and LeCompte 1981), data from the interviews were related to literature reviews on CSR (Schwartz and Carroll 2008; Singhapakdi et al. 1996), to reviews on individual motives for and payoffs of AMCV involvement (Peloza and Hassay 2006) and to reviews on pro-social motivation at work (Grant and Berg 2010). Theoretical coding was subsequently adopted as a point of saturation was reached, with no new categories emerging (Glaser 1992). COI scores for each of the eight career anchors and their relative ranking by each of the respondents were calculated arithmetically, according to specified scoring procedures (Schein 1993), and were compared with data from the biographical data sheets and interviews.

\section{Findings}

The integrity and commitment of firms' adoption of AMCV

What is perceived as the prevailing strategic approach that firms have been adopting for AMCV? (RQ1) Seven of the ten host firms were perceived as having 
adopted strategically instrumental approaches to AMCV, as illustrated by these comments by paid organisers:

For me, [AMCV] is not just about providing community service activities but is part of a multi-dimensional business, and also serves employees and stockholders. By balancing these aspects, this company can be regarded as a socially responsible company. [EFPO1].

Corporations participating in AMCV can leverage their expertise and resources to contribute to our society and help those in need, and our firm aspires to be a pioneer within our industry. It is an opportunity for us to change the life attitude of our community, and it can change our clients' perceptions of us. [DFPO1].

Two respondents perceived that their respective firms had adopted altruistic approaches to AMCV.

Our company wishes to contribute back to society through helping those in need with a sincere heart. Therefore media releases are not that important to us. That's why we are very low key about [AMCV]. We allocate an annual budget to such activities. I highly appreciate that we have contributed in such a sincere and low-key manner. [GFV1].

Prior to the Caring Company Scheme, activities to help the local community had been organized by enthusiastic colleagues for 10 years, offering services and sometimes cooperating with NGOs to hold various functions. These were low key, since the company did not formally run them, but the human resource department supported them comprehensively by providing funds and logistical support. Then, after our new CEO arrived, our company joined the Caring Company Scheme, and the organizers asked us to implement [AMCV] formally. [CMUO1].

Only one firm was characterised as having adopted an opportunistic approach, as follows:

Our company just treats [AMCV] as a kind of investment with return, whereas in terms of my own perspective, I think that true [AMCV] activities should really contribute something back to the society, by helping people. [HMUO1].

What signs are there, if any, of a lack of commitment by firms to community service? (RQ2) Respondents expressed relatively few reservations about whether firms were genuinely committed to community service provision in their approach to AMCV. One such isolated comment was:

Ultimately, firms' only concern is their own image. The goal is to build up their image. I cannot say that this is right or wrong, but their objective is obviously about image. [NM1].

What signs are there, if any, of a lack of integrity by firms in operating AMCV? (RQ3) Respondents made relatively few comments that suggested that firms 
were lacking integrity in the way they were operating AMCV. One such comment was:

From the company's perspective, [AMCV] is only worth it if it has value for the business. It is just a kind of commercial gimmick designed to attract more potential clients. [HMV1].

What are the main roles of paid AMCV organisers in firms? (RQ4) Four of the five AMCV organisers in our sample had job titles that referred to public relations or corporate communication. All five, nonetheless, described extensive involvement in arranging the provision of voluntary services to the community and regarded such work as a major aspect of their respective roles. Illustrative quotes are as follows:

The most important issue for me is that my job allows me to help people in need. [DFPO1].

I don't have any specific expectations other than serving the people. [EFPO1].

I am really satisfied that I can help those in need through my full-time job. It's more influential than just being a volunteer. I can allocate company resources to encourage people to help the needy. [JFPO1].

What corporate payoffs are firms perceived to seek from AMCV? (RQ5) Many respondents believed that firms were adopting AMCV for purposes that were related to public relations and/or to organisational development. Typical comments were:

You need to get back some media exposure. This is essential, so as not to waste the company's money. [EFPO1].

Firms partnering with us want to develop stronger internal cohesion and they want to sharpen their brand name as a caring company. [NF2].

We organize activities that are intended to help increase employees' loyalty, which happens gradually and takes time to build up. Participating in these activities can contribute to office harmony and we expect that this will increase productivity because of a higher employee retention rate. [AFUO1].

One respondent gave an example of what he considered to be his firm's publicityseeking intention 'after the fact', in reaction to other events.

Recently, our firm made an unpopular decision... [about charging policies] due to business considerations, and there had been a strongly adverse public reaction, with some people blaming and challenging us with lots of noise. At that time, since we had already done lots of community caring services, we published a series of items over several weeks in Metro News to showcase such services... If someone wants to attack you, you have the proof showing that you are not just concerned about making profit, but that you also care about the community. [CMUO1]. 
What are perceived to be the actual payoffs for firms from AMCV? (RQ6) Interviewees appeared to perceive that firms were achieving their goals for AMCV in terms of improved public relations, stronger internal cohesiveness, greater employee loyalty and achievement of various training and development outcomes.

I believe that organizing [AMCV] activities has improved internal communication, and has helped to create a positive corporate image. [JFPO1].

Last week, the volunteers had a hard day replanting some flowering plants. They needed to move them from the roof top ... to the top of the mountain. It was very hard for them to do, but it built up team spirit and a cooperative culture among the colleagues. [CMU02].

Volunteering activities improve cross-departmental cooperation and collaboration. They also provide a very good platform for project management training. [AMUO2].

Exposure to the less fortunate is a kind of value-based training and development experience. Only through helping those who are in need can we really come to treasure what we possess and learn to be grateful. Once we are committed to such values and attitudes, we can also commit to honesty and integrity, which are key professional values. [GFV1].

I am really happy to know that my company cares about society and the environment this much. I am really proud of being their employee. [HFV2].

What are perceived as the main societal benefits of AMCV? (RQ7) Nearly all respondents stated that $\mathrm{AMCV}$ was producing real value for society, but they did not spell such benefits out in detail. A typical comment was as follows:

The underprivileged members of society can receive more help because of the ability of corporations such as ours to share their resources. This helps to fill the gap that government cannot address due to limited resources. [JFPO1].

What is perceived to characterise the working relationships that firms develop with NGOs? (RQ8) Comments by the firm-based respondents indicated that they regarded NGOs as convenient channels into community service work rather than as service recipients in their own right. The NGO respondents perceived that the quality of firm-NGO relationships ranged from mediocre to excellent. While they hinted that some firms might even be exploiting NGOs as advertising channels, they indicated that most firms were emphasising service provision and that some firms were contributing to the NGOs' development. Illustrative comments are given below:

I cannot say for sure that firms are using us, but I think they might be [NM1].

[Firm I] just want to utilize the media to promote their corporation for future business. We expect this and regard it as normal. But with [Firm I] this is so 
obvious. That's why collaboration with them is very difficult sometimes. Unquestionably, they do have a good heart to serve the society. We never suspect that. However, they have another motive. It was obvious that they kept on continuously promoting their corporation during particular events. We need to accept that since it is win-win. They took what they wanted and so do we. But [Firm I] calculates everything in detail and they are very tight in cost control. In my experience in collaborating with them, they cannot give you money, but only supply human resources. For some events, it is as if they are performing a show. If Donald Tsang [Hong Kong's Chief Executive] comes along, they give him a high profile role. It is obvious that Firm I treats us as an advertising tool. We just let it happen, but fortunately not all companies operate like this. [NF1].

I have had some unhappy experiences with firms, due to insufficient mutual understanding. It depends on the liaison person. Even within the same company, you feel surprised how differently the various liaison people think. I focus on the positive side. No matter whether my counterparts need to 'hand in their homework' or to sharpen the brand name of their firm, I still think that [AMCV] is a beautiful and praiseworthy arrangement. Collaborating with outsiders has made us consider new angles as social workers. We complement each other. Collaboration without inappropriate expectations helps to develop their staff and to develop our own staff. They have strengthened our professionalism. Those with whom we collaborate happily are good people concerned about benefitting society and the employees. Their primary intention is to meet people's needs rather than to benefit the firm. [NF2].

To what extent is participation in AMCV by employees genuinely voluntary? (RQ9) Most comments indicated that volunteers were being recruited non-coercively. For example:

The firm provides a platform for us to join those activities that we like. [IFV2].

Current volunteers offer their services with sincerity and of their free will. They also tend to invite their co-workers to join the volunteering activities. These are genuinely voluntary and we don't have any mechanisms to force people to join in. [CMUO2].

I just wanted to give it a try. However, ever since I got involved, I have been in love with such activities. [IMV2].

However, the following comments suggested that, in some parts of some firms and on some occasions, AMCV 'volunteers' had been coercively recruited.

No one has any excuse to reject invitations. [AFUO1].

Because of departmental pressure, I participated just for the sake of keeping my job. [HMV1]. 
Someone came along involuntarily, and said, 'Please hurry. I have an appointment with someone soon!' Each year, [Firm I] has a 'caring day'. When the big boss sees that one subsidiary is only sending 5 people but another is sending 50, the boss of that subsidiary will face pressure, and will force people to go. Each subsidiary pushes its people to join. [NF1].

Establishing motives for employee volunteering

To what extent does AMCV provide a bridge to enlist those employees, who would otherwise not undertake volunteer work? (RQ10) It appeared that, among the 24 firm-based respondents, AMCV had rekindled the interest of one employee and had provided the first experience of volunteering work for 13 employees. The following comments provide illustrations:

I had already 'tasted' volunteer work, so it was not something new and strange for me, but I had stopped for a long time until my boss invited me, and then I re-activated. [CMUO1].

[AMCV] draws together people, who would otherwise never get involved in community service... but who have latent passion for providing community service [AMUO1].

You would never search for community service work on your own. [IFV2].

The company provides a platform to participate in [AMCV] activities, which are hard to access without a network and proper information. [IMV1].

What are the motives for ongoing involvement in AMCV among volunteers? (RQ11) Motives corresponding to altruism, egoism, principlism, collectivism and understanding were evident in respondents' accounts. While most respondents mentioned that altruism was a factor driving their ongoing involvement in $\mathrm{AMCV}$, this appeared to be combined with other motives, such as building relationships with service recipients (a type of collectivism) and with feelings of being effective in making a difference (a form of egoism). The following comments illustrate how altruism was mixed with and reinforced by other motives.

When service recipients feel happy, I'm happy too, as I feel that I have been able to help. A patient at the-hospital treats me as his big sister. One day, he asked if he could pick all the chillies from the pot as a gift to thank me. It was so touching. [IFV3].

When I was teaching the learning-disabled, they were so happy and excited. As we were leaving, they grabbed my hand and didn't want to let go. I could see in their eyes their eagerness to make us stay. Their happiness and excitement moved me and made me feel happy and serene. [IMV1]. 
One of the mentally-ill patients composed a song for us, telling us that when he recovers, he'd also like to join our volunteer team. It was so touching. [IMV2].

I treasure my relationship with the children. Every time you return to the centre, you find they have grown up a little and have gained improvements. It's so encouraging. [GFV1].

In terms of egoism, the main gains referred to the transformational impact of AMCV on individuals. Some respondents said that they had developed greater social confidence:

Initially I was really scared by the learning-disabled students. However, through the activities, I found that they are so cute, creative and carefree. [IFV1].

Participating in such activities converted me to Christianity. I previously had a stammer, could not speak well, and lacked confidence. After participating in these activities, my communication and interpersonal skills have greatly improved. [IMV2].

Some respondents alluded to principlism, either related to religious faith or to identification with those in need:

Maybe because of my religion, a maxim comes to mind: others help you when you have difficulties, so you should help others if they have difficulties. [CMUO1].

I am from a poor family, and lived in a public housing estate for nearly 20 years. It was very hard for us, and you realize the need to help people, who are like those who played with me in my childhood, and who are at risk of going in a wrong direction. As I had a childhood like that, I know why some people need help, and I want to help as much as I can. [CMUO2].

In terms of collectivism, besides providing opportunities to develop relationships with service recipients, AMCV involvement also allowed volunteers to express loyalty to their company, spend time with friends, build solidarity with colleagues and meet new friends.

I can show my support for my company and at the same time I can help the needy ones in my spare time. I found it very meaningful and so-called 'cost effective'. [AMUO1].

It's a good opportunity to meet committed friends across departments. Our scheme also encourages participants to bring their family. We organized a summer camp to bring children to work as volunteers. It wasn't like a formal event but was organized in a free-style. I made some new friends there, including a cousin of one of my colleagues. [CMUO1]. 
Some accounts indicated that developing greater understanding and, more specifically, gaining insight into suffering or deprivation mobilized ongoing participation.

I didn't expect so many children suffering various kinds of handicap, illness, or injury such as severe burns. I was quite shocked upon my arrival and I really pitied them, even though we had been briefed before we got there. [HFV2].

Whenever [the AMCV volunteers] have finished the service, we have a debriefing. Some have been deeply moved... This has been an occasion for deep reflection. [NF1].

Career anchors and mode of individual involvement in AMCV

Tables 3 and 4 summarize the mean aggregate COI scores and the relative incidence of principal career anchors, respectively.

What is the relative incidence of the SV career anchor? (RQ12) Of the eight career anchors, SV had the second highest incidence among the whole sample of respondents. However, the SV career anchor was unevenly spread among the four different types of AMCV participant. The highest concentration of the SV career anchor was among employees at partner NGOs. Among this group, all three respondents had this as their sole principal career anchor and stated that their future careers would focus on helping people in need. Typical interview comments by NGO employees expressing the SV career anchor among were:

I was born to be a caring person. I have had this mindset from when I was small. [NF1].

As a child, I knew that I should serve the people.... One thing I didn't change is that I still want to serve the people. [NF2].

Among the five firm-based, paid AMCV organisers, three had SV as their principal career anchor, while the other two rated SV second or equal second. All

Table 3 Mean aggregate COI scores among four categories of AMCV participant

\begin{tabular}{lrlllllllll}
\hline & \multicolumn{1}{c}{ COI career anchors } & & & & \\
\cline { 3 - 10 } AMCV-related roles & $N$ & SV & LS & SE & AU & TF & GM & EC & CH \\
\hline Respondents at partner NGOs & 3 & 8.7 & 6.7 & 4.8 & 6.5 & 5.4 & 2.8 & 2.7 & 3.5 \\
Firm-based paid organisers & 5 & 5.4 & 4.8 & 3.4 & 4.8 & 3.6 & 2.9 & 3.5 & 3.3 \\
Unpaid voluntary organisers-cum-participants & 6 & 4.2 & 7.4 & 6.2 & 6.0 & 4.8 & 3.9 & 4.0 & 4.0 \\
Voluntary participants without organiser roles & 13 & 3.9 & 4.5 & 4.5 & 4.0 & 3.9 & 3.3 & 3.6 & 3.2 \\
Means & 27 & 4.7 & 5.4 & 4.7 & 4.9 & 4.2 & 3.3 & 3.6 & 3.4 \\
\hline
\end{tabular}


Table 4 Incidence of principal career anchors among four categories of AMCV participant

Incidence of career anchors

\begin{tabular}{lrrrrrrrrr} 
AMCV-related roles & $N$ & SV & LS & SE & AU & TF & GM & EC & CH \\
\hline Respondents at partner NGOs & 3 & 3 & 0 & 0 & 0 & 0 & 0 & 0 & 0 \\
Firm-based paid organisers & 5 & 3 & 1 & 1 & 0 & 0 & 0 & 0 & 0 \\
Unpaid voluntary organisers-cum-participants & $6^{\mathrm{a}}$ & 1 & 4 & 1 & 0 & 1 & 0 & 0 & 0 \\
Voluntary participants without organiser roles & $13^{\mathrm{a}}$ & 1 & 1 & 7 & 2 & 3 & 1 & 2 & 1 \\
Totals & $27^{\mathrm{a}}$ & 8 & 6 & 9 & 2 & 4 & 1 & 2 & 1
\end{tabular}

${ }^{\text {a }}$ Principal career anchors total more than $N$, owing to ties for the highest scoring COI ratings

five stated that they intended to continue in careers that would either focus on AMCV or would be more broadly CSR-related.

Among the 19 other respondents (the six firm-based, unpaid, voluntary organisers-cum-participants and the 13 firm-based volunteers), only two had SV as their principal career anchor, and SV received only moderate aggregate COI scores. Most of these other respondents intended to continue their existing mode of participation in AMCV, but none envisaged shifting to paid employment in NGOs, becoming paid firm-based AMCV organisers or taking up posts with other types of CSR-related responsibilities.

What career anchors other than SV are prominent? (RQ13) Among the six firmbased, unpaid, voluntary organisers-cum-participants, LS received the highest aggregate COI scores and was the principal career anchor for four respondents. LS is characterised by concern to balance or integrate personal, family and career needs, with personal identity related to total lifestyle, rather than linked to a particular job or organisation (Schein 1993).

Among the 13 firm-based, AMCV volunteers without organiser roles, SE received the highest aggregate COI scores and was a principal career anchor (including ties) for seven out of the 13 respondents. Employees with SE as a principal career anchor tend to feel a strong need for stable employment and financial security, value loyalty to their employer and seek to conform to their employer's expectations (Schein 1993). Besides this leaning towards SE, there was also considerable diversity within this group in terms of career anchor preferences, such that each of the eight career anchors was ranked first or first equal by at least one respondent.

\section{Summary and conclusions}

Respondents perceived that the firms with which they were involved were tending to adopt strategic instrumental approaches to AMCV rather than altruistic approaches. It appeared that the advent of the Caring Company Scheme had induced firms to move away 
from informal approaches to AMCV. Some respondents alluded to isolated signs of opportunistic approaches by firms, where there was not a consistently high level of corporate commitment and integrity in operating AMCV. It appeared, nonetheless, that in operating $\mathrm{AMCV}$, most of the firms and all of the paid AMCV organisers featuring in this study were committed to supplying meaningful voluntary work to serve people in need or the community as a whole, in combination with corporate image promotion and culture development. Most respondents believed that AMCV had been a source of genuine value for service recipients and/or for society as a whole and that AMCV had also been valuable for the firms and for volunteers themselves. Employees at partner NGOs tended to be more critical of the commercial goals of $\mathrm{AMCV}$, and some of their comments pointed to the risk that if commercial goals were narrowly and exaggeratedly emphasised, they could detract from a strategically instrumental approach and turn it into an opportunistic one.

It appeared that AMCV was providing a bridge into volunteer work. Through AMCV, employees were gaining easy access to partner NGOs and host venues, were being offered a menu of choices, were receiving briefings on how to provide services and were being reassured that volunteering would not be a lonely task that would be performed in the midst of strangers. Among the volunteers, altruism appeared to be a strong driver and, to a lesser extent, principlism, often in combination with warm feelings associated with making a difference, building relationships with service recipients, developing greater social confidence and gaining understanding. Other collectivist motives, such as demonstrating support for the company and building friendships among colleagues, also appeared important.

The SV (service/dedication to a cause) career anchor predominated among NGObased respondents and among firm-based paid AMCV organisers, but not among firm-based, unpaid, voluntary AMCV organisers-cum-participants, who preferred LS (life balance), or among firm-based, voluntary AMCV participants without organiser roles, who leaned toward SE (loyalty and belonging).

In terms of practical implications, we suggest that the Caring Company Scheme should carefully monitor the quality of firms' collaborative engagement with partner NGOs and their methods of recruiting volunteers, should provide feedback to firms about welcome and unwelcome corporate practices and should advise firms on how to avoid unwittingly pressurizing subordinates to 'volunteer'.

Beyond the examples found in the present research study, we envisage that firms and NGOs could, to the benefit of all parties, develop additional types of collaborative arrangement that would help to build the capabilities of NGOs themselves, while also broadening the suite of volunteering opportunities that are available to employees and offering matches with the full range of career anchors. For example, a professional with $\mathrm{TF}$ as his/her principal career anchor might be attracted by opportunities to undertake pro bono work (Galbally 2007), an employee with the GM career anchor might welcome the chance to serve on a high-level committee of an NGO and an employee with the EC career anchor might enjoy helping to set up and support a social enterprise. These and other matches between volunteering opportunities and career anchors are suggested in Table 5.

Our research had some limitations. First, it is possible that some of the contact people, who supplied our firm-based respondents, selected those colleagues, whom they considered likely to provide favourable comments about AMCV, while screening out colleagues, whom they considered likely to voice criticisms. Notably, 
Table 5 Career anchors and matching roles and activities relating to corporate volunteerism

\begin{tabular}{|c|c|c|}
\hline Career anchors & Characteristic values and skills & $\begin{array}{l}\text { Examples of matching volunteering } \\
\text { roles or activities }\end{array}$ \\
\hline $\begin{array}{l}\text { Technical/functional } \\
\text { competence }\end{array}$ & $\begin{array}{l}\text { Applying and continuously } \\
\text { developing discipline-based skill }\end{array}$ & $\begin{array}{l}\text { Applying specialist professional } \\
\text { or technical skills to an NGO } \\
\text { on a pro bono basis }\end{array}$ \\
\hline $\begin{array}{l}\text { General managerial } \\
\text { competence }\end{array}$ & $\begin{array}{l}\text { Opportunity to manage others } \\
\text { across an organisation for results }\end{array}$ & $\begin{array}{l}\text { Serving on the board of an NGO; } \\
\text { assuming responsibility for a } \\
\text { firm's overall CSR policies } \\
\text { and activities }\end{array}$ \\
\hline Autonomy/independence & $\begin{array}{l}\text { Enduring freedom to control } \\
\text { one's own activities }\end{array}$ & $\begin{array}{l}\text { Obtaining unpaid leave to } \\
\text { perform self-initiated } \\
\text { volunteer work via } \\
\text { approved NGOs }\end{array}$ \\
\hline Security/stability & Financial or job security & $\begin{array}{l}\text { Gaining recognition within } \\
\text { the firm for undertaking } \\
\text { regular volunteer work }\end{array}$ \\
\hline $\begin{array}{l}\text { Entrepreneurial } \\
\text { creativity }\end{array}$ & $\begin{array}{l}\text { Creating one's own enterprise } \\
\text { based on personal endeavour }\end{array}$ & $\begin{array}{l}\text { Helping to set up and ensure } \\
\text { the sustainability of a } \\
\text { social enterprise }\end{array}$ \\
\hline $\begin{array}{l}\text { Service/dedication } \\
\text { to a cause }\end{array}$ & $\begin{array}{l}\text { Achieving something of benefit } \\
\text { or value to others }\end{array}$ & $\begin{array}{l}\text { Full-time employment as a } \\
\text { firm-based paid organiser } \\
\text { of AMCV; opportunity } \\
\text { to experience 'making } \\
\text { a difference' }\end{array}$ \\
\hline Pure challenge & $\begin{array}{l}\text { Seeking to achieve the almost } \\
\text { impossible }\end{array}$ & $\begin{array}{l}\text { Unpaid leave to join a task } \\
\text { force to address a social } \\
\text { problem or help in } \\
\text { disaster recovery }\end{array}$ \\
\hline Life style & $\begin{array}{l}\text { Harmony between personal, family } \\
\text { and work position }\end{array}$ & $\begin{array}{l}\text { Organising AMCV activities } \\
\text { on a voluntary basis }\end{array}$ \\
\hline
\end{tabular}

all three NGO respondents expressed reservations and concerns about some firms' goals for and operation of AMCV, while the great majority of firm-based respondents did not. Second, we did not include a comparison group of nonparticipants in AMCV among our respondents, so we were not able to study reasons for non-participation by people in firms that have an AMCV infrastructure. Third, the sample of organisations was small, comprising only three NGOs and ten firms, and may not have been representative. Fourth, the sample of individual respondents was too small to support statistical tests about the relationship between career anchors and the various AMCV-related roles.

A fifth limitation was that because of the small sample size, no attempt was made to analyse the impact of demographic factors, such as religion, education, gender, social status and income, on employees' motivation to volunteer (Wilson 2000), or on their mode of participation in AMCV. Notably, religiosity predicts volunteer activity (Ruiter and De Graaf 2006; Taniguchi 2010), and a high proportion of respondents in the current study were Christians. Further research could seek to examine, or at least control for, the relationship 
between demographic factors and AMCV, both at the level of the firm and at the level of the individual employee. However, such research would need to investigate the possibility of reverse causality between volunteering and dynamic factors such as religion and education. For example, one respondent in the current study claimed that his volunteering experience had precipitated his own religious conversion.

Further research might also examine effective ways for firms to locate, manage and integrate the AMCV organiser function within their overall organisational design (Bondy 2008) and could investigate why some firms do not develop AMCV infrastructure. It could also explore the full range of career paths open to AMCV organisers, within or outside the broader field of CSR, and could further assess the relative importance to AMCV organisers of the SV career anchor.

Declaration The study reported in the paper was approved by the appropriate ethics committee and was therefore performed in accordance with the ethical standards laid down in the 1964 Declaration of Helsinki. All persons gave their informed consent prior to their inclusion in the study. Details that might disclose the identity of the subjects under study have been omitted.

\section{References}

Andreoni, J. (1990). Impure altruism and donations to public goods: A theory of warm-glow giving. Economic Journal, 100, 464-477.

Anonymous. (2004). Who cares? British Journal of Administrative Management, 41(2), 18-19.

Arnold, J., Cooper, C. L., \& Robertson, I. T. (1998). Work psychology: Understanding human behaviour in the workplace. London: Pitman.

Austin, J. E. (2000). The collaboration challenge: How nonprofits and businesses succeed through strategic alliances. San-Francisco: Jossey-Bass.

Banerjee, S. (2007). Corporate social responsibility: The good, the bad and the ugly. Cheltenham: Edward Edgar.

Bang, H., \& Ross, H. D. (2009). Volunteer motivation and satisfaction. Journal of Venue and Event Management, 1(1), 61-77.

Bates, A., \& Kim, J. (2008). Riding the big wave of corporate volunteering. Proceedings of the 12th National Conference on Volunteering. Gold Coast: Volunteering Australia. http://www.volunteeringaustralia.org/ files/IIZ2L2APC7/bn08004_VA8_Alan\%20Bates.pdf. Accessed 8 July 2010.

Batson, C. D. (1987). Prosocial motivation: Is it ever truly altruistic? In L. Berkowitz (Ed.), Advances in experimental social psychology (Vol. 20, pp. 65-122). New York: Academic.

Batson, C. D. (1994). Why act for the public good? Four answers. Personality and Social Psychology Bulletin, 20(5), 603-610.

Batson, C. D., Ahmad, N., Powell, A. A., \& Stocks, E. L. (2008). Prosocial motivation. In J. Y. Shah \& W. L. Gardner (Eds.), Handbook of motivation science (pp. 135-149). New York: Guilford.

Bondy, K. (2008). The paradox of power in CSR: A case study on implementation. Journal of Business Ethics, 82(2), 307-323.

Bory, A. J. (2007). The effects of volunteering on the work environment: A study of French Corporate Volunteerism. Presented at the 102nd Annual Meeting of the American Sociological Association, New York. http://citation.allacademic.com/meta/p_mla_apa_research_citation/1/8/4/1/0/pages 184103/ p184103-1.php. Accessed 14 July 2011.

Brown, J. (1997). Review of social responsibility and the company: A new perspective on governance, strategy and the community. Social Policy Journal of New Zealand Te Puna Whakaaro, 9.

Burke, L., Logsdon, J. M., Mitchell, W., Reiner, M., \& Vogel, D. (1986). Corporate community involvement in the San Francisco Bay Area. California Management Review, 28(3), 122-141. 
Carroll, A. B. (1979). A three-dimensional conceptual model of corporate performance. Academy of Management Review, 4(4), 497-505.

Carroll, A. B. (1991). The pyramid of corporate social responsibility: Toward the moral management of organizational stakeholders. Business Horizons, 34, 39-48.

Cavallaro, L. (2007). Corporate volunteering: What employers and employees really think. Australian Journal on Volunteering, 12(1), 52-56.

Chell, E. (1999). Critical incident technique. In G. Symon \& C. Cassell (Eds.), Qualitative methods and analysis in organizational research (pp. 51-72). London: Sage.

Chen, M.-J., Farh, J.-L., \& MacMillan, I. C. (1993). An exploration of the expertness of outside informants. Academy of Management Journal, 36(6), 1614-1632.

Clary, E. G., Snyder, M., Ridge, R. D., Copeland, J., Stukas, A. A., Haugen, J., et al. (1998). Understanding and assessing the motivations of volunteers: A functional approach. Journal of Personality and Social Psychology, 74(6), 1516-1530.

Coupland, C. (2006). Corporate social and environmental responsibility in web-based reports: Currency in the banking sector? Critical Perspectives on Accounting, 17(7), 865-881.

Danziger, N., Rachman-Moore, D., \& Valency, R. (2008). The construct validity of Schein's career anchors orientation inventory. Career Development International, 13(1), 7-19.

Danziger, N., \& Valency, R. (2006). Career anchors: Distribution and impact on job satisfaction, the Israeli case. Career Development International, 11(4), 293-303.

Dovidio, J. F., Piliavin, J. A., Schroeder, D. A., \& Penner, L. A. (2006). The social psychology of prosocial behaviour. Mahwah: Lawrence Erlbaum.

Flanagan, J. C. (1954). The critical incident technique. Psychological Bulletin, 51(4), 327-358.

Freeman, E. (1984). Strategic management: A stakeholder approach. Englewood Cliffs: Prentice-Hall.

Freeman, E. (1994). The politics of stakeholder theory: Some future directions. Business Ethics Quarterly, 4(4), 409-421.

French, P. (1979). The corporation as a moral person. American Philosophical Quarterly, 16(3), $207-215$.

Friedman, M. (1970). The social responsibility of business is to increase its profits. New York Times Magazine, pp 32-33, 122, 124, 126. September 13.

Frisch, M. B., \& Gerrard, M. (1981). Natural helping systems: Red Cross volunteers. American Journal of Community Psychology, 9(5), 567-579.

Frost, P. J., Dutton, J. E., Maitlis, S., Lilius, J. M., Kanov, J. M., \& Worline, M. C. (2006). Seeing organizations differently: Three lenses on compassion. In S. R. Clegg, C. Hardy, T. B. Lawrence, \& W. R. Nord (Eds.), The Sage handbook of organization studies (2nd ed., pp. 843866). London: Sage.

Galbally, R. (2007). Corporate volunteers need to look harder at where they can help. Sydney Morning Herald, 13 September, 2007. http:/www.smh.com.au/small-business/corporate-volunteers-need-tolook-harder-at-where-they-can-help-20090619-couc.html. Accessed 14 July 2011.

Gibson, K. (1990). The moral basis of stakeholder theory. Journal of Business Ethics, 26(3), 245-257.

Gilchrist, V. J. (1992). Key informant interviews. In B. Crabtree \& W. Miller (Eds.), Doing qualitative research (pp. 70-89). Newbury Park: Sage.

Gill, R. W. T., \& Leinbach, L. J. (1983). Corporate social responsibility in Hong Kong. California Management Review, 25(2), 107-123.

Glaser, B. G. (1992). Basics of grounded theory analysis. Mill Valley: Sociology.

Global Corporate Volunteer Council. (2011). The state of health of corporate volunteering: Executive summary. Singapore: International Association for Volunteer Effort. http:/www.iave.org/content/statehealth-corporate-volunteering. Accessed 15 July 2011.

Goetz, J. P., \& LeCompte, M. D. (1981). Ethnographic research and the problem of data reduction: What do I do with the five drawers of field notes? Anthropology and Education Quarterly, 12(1), 51-70.

Goffee, R., \& Jones, G. (1998). The character of a corporation. New York: Harper Collins.

Gouldner, A. W. (1973). The importance of something for nothing. In A. W. Gouldner (Ed.), For sociology: Renewal and critique in sociology today (pp. 260-299). London: Allen Lane.

Grant, A. M. (2008). The significance of task significance: Job performance effects, relational mechanisms, and boundary conditions. Journal of Applied Psychology, 93(1), 108-124.

Grant, A. M., \& Berg, J. M. (2010). Prosocial motivation at work: When, why and how making a difference makes a difference. In K. Cameron \& G. Spreitzer (Eds.), Handbook of positive organizational scholarship. Oxford: Oxford University Press. http:/www.management.wharton. upenn.edu/grant/GrantBerg_POSHandbookFinal.pdf. Accessed 11 June, 2010.

Grant, A. M., \& Berry, J. (2011). The necessity of others is the mother of invention: Intrinsic and prosocial motivations, perspective-taking, and creativity. Academy of Management Journal, 54(1), 73-96. 
Haski-Leventhal, D. (2009). Altruism and volunteerism: The perceptions of altruism in four disciplines and their impact on the study of volunteerism. Journal for the Theory of Social Behaviour, 39(3), 271-299.

Hemingway, C. A., \& Maclagan, P. W. (2004). Managers' personal values as drivers of corporate social responsibility. Journal of Business Ethics, 50(11), 33-44.

Hoffman, M. L. (1978). Psychological and biological perspectives on altruism. International Journal of Behavioural Development, 1(4), 323-339.

Houghton, S. M., Gabel, J. T. A., \& Williams, D. W. (2009). Connecting the two faces of CSR: Does employee volunteerism improve compliance? Journal of Business Ethics, 87(4), 477-494.

Hudson, S., \& Inkson, K. (2006). Volunteer overseas development workers: The hero's adventure and personal transformation. Career Development International, 11(4), 304-320.

Jamali, D., \& Keshishian, T. (2009). Uneasy alliances: Lessons learned from partnerships between businesses and NGOs in the context of CSR. Journal of Business Ethics, 84(2), 277-295.

Kniveton, B. H. (2004). Managerial career anchors in a changing business environment. Journal of European Industrial Training., 28(7), 564-573.

Kumar, N. L., Stern, W., \& Anderson, J. C. (1993). Conducting interorganisational research using key informants. Academy of Management Journal, 36(6), 1633-1651.

Lantos, G. P. (2001). The boundaries of strategic corporate social responsibility. Journal of Consumer Marketing, 18(7), 595-630.

Lau, S. K. (1982). Society and politics in Hong Kong. Hong Kong: Chinese University Press.

Loza, J. (2004). Business-community partnerships: The case for community organization capacity building. Journal of Business Ethics, 53(3), 297-311.

Lynn, P., \& Davis Smith, J. (1995). National survey of voluntary activity, 1991. Computer file. SN: 3460. Colchester: UK Data Archive (distributor).

Mantel, S., Cheung, D., Welford, R., \& Hills, P. (2007). Cooperation for environmental reform: BusinessNGO partnerships in Hong Kong. Journal of Corporate Citizenship, 27, 91-106.

Marshall, M. N. (1996). Sampling for qualitative research. Family Practice, 13(6), 522-525.

McAlister, D. T., \& Ferrell, L. (2002). The role of strategic philanthropy in marketing strategy. European Journal of Marketing, 36(5/6), 689-705.

Metzer, J. C. (1996). The psychology of volunteering: External or internal rewards? Australian Journal on Volunteering, 1(2), 20-24.

Metzer, J. C. (2003). Volunteering work stress and satisfaction at the turn of the 21 st century. In M. F. Dollard, A. H. Winefield, \& H. R. Winefield (Eds.), Occupational stress in the service professions (pp. 389-407). London: Taylor \& Francis.

Miles, M., \& Huberman, A. (1994). An expanded source book: Qualitative data analysis (2nd ed.). London: Sage.

Moorman, R. H., \& Blakely, G. L. (1995). Individualism-collectivism as an individual difference predictor of organizational citizenship behavior. Journal of Organizational Behavior, 16(2), 127142.

Morrow-Howell, N., \& Mui, A. (1989). Elderly volunteers: Reasons for initiating and terminating service. Journal of Gerontological Social Work, 13(3/4), 21-34.

Norman, W., \& MacDonald, C. (2004). Getting to the bottom of "triple bottom line". Business Ethics Quarterly, 14(2), 243-262.

Owen, D. L., Swift, T. A., Humphrey, C., \& Bowerman, M. (2000). The new social audits: Accountability, managerial capture or the agenda of social champions? European Accounting Review, 9(1), 81-98.

Parsons, P. J. (2004). Ethics in public relations: A guide to best practice. London: Institute of Public Relations.

Pearce, L. P., \& Herbik, P. A. (2004). Citizenship behaviour at the team level of analysis: The effect of team leadership, team commitment, perceived team support and team size. Journal of Social Psychology, 144(3), 293-310.

Peloza, J., \& Hassay, D. N. (2006). Intra-organizational volunteerism: Good soldiers, good deeds and good politics. Journal of Business Ethics, 64(4), 357-379.

Perren, L., \& Morland, R. (1999). Simon's story: An intimate history of career change. Career Development International, 4(4), 244-250.

Post, J. E., Lawrence, A. T., \& Weber, J. (2002). Business and society: Corporate strategy, public policy, ethics (10th ed.). Boston: McGraw-Hill Irwin.

Powers, M. (1998). Life cycles and volunteering. Human Ecology Forum, 26(3), 3-9.

Quirk, D. (1998). Corporate volunteering: The potential and the way forward. Wellington: Volunteer Centre. 
Ralston, D. A., Gustafson, D. J., Cheung, F., \& Terpstra, R. H. (1993). Differences in managerial values: A study of U.S., Hong Kong and PRC managers. Journal of International Business Studies, 24(2), 249-275.

Ramasamy, B., \& Yeung, M. (2009). Chinese consumers' perception of corporate social responsibility (CSR). Journal of Business Ethics, 88(Supplement 1), 119-132.

Redding, S. G. (1990). The spirit of Chinese capitalism. Berlin: Walter de Gruyter.

Reed, D. (1999). Stakeholder management theory: a Critical theory perspective. Business Ethics Quarterly, 9(3), 453-483.

Ruiter, S., \& De Graaf, N. D. (2006). National context, religiosity, and volunteering: Results from 53 countries. American Sociological Review, 71(2), 191-210.

Saiia, D. H., Carroll, A. B., \& Buchholtz, A. K. (2003). Philanthropy as strategy when corporate charity "begins at home". Business \& Society, 42(2), 169-201.

Sandberg, J. (1994). Human competence at work: An interpretative approach. Goteborg: Bas.

Schein, E. H. (1978). Career dynamics: Matching individual and organizational needs. Reading: AddisonWesley.

Schein, E. H. (1993). Career anchors: Discovering your real values (revised ed.). London: Pfeiffer \& Company.

Schein, E. H. (1996). Career anchors revisited: Implications for career development in the 21 st century. Academy of Management Executive, 10(4), 80-88.

Schwartz, M., \& Carroll, A. (2008). Integrating and unifying competing and complementary frameworks: The search for a common core in the business and society field. Business \& Society, 47(2), 148-186.

Shin, S., \& Kleiner, B. H. (2003). How to manage unpaid volunteers in organisations. Management Research News, 26(2/3/4), 63-71.

Sing, M. (2009). The quality of life in Hong Kong. Social Indicators Research, 92(2), 295-335.

Sims, R. R., \& Brinkmann, J. (2003). Enron ethics (Or: Culture matters more than codes). Journal of Business Ethics, 45(3), 243-256.

Singhapakdi, A., Vitell, S., Rallapalli, K., \& Kraft, K. (1996). The perceived role of ethics and social responsibility: A scale development. Journal of Business Ethics, 15(11), 1131-1140.

Steele, C. A. (2009). Measuring career anchors and investigating the role of career anchor congruence. Unpublished doctoral dissertation, University of Coventry, in collaboration with the University of Worcester, UK. http://eprints.worc.ac.uk/705/. Accessed 15 July 2011.

Strauss, A., \& Corbin, J. (1990). Basics of qualitative research: Grounded theory procedures and techniques. London: Sage.

Taniguchi, H. (2010). Who are volunteers in Japan? Nonprofit \& Voluntary Sector Quarterly, 39(1), 161179.

Teague, D. E. (2008). Employee volunteerism: Social benefits trump altruism. Unpublished doctoral research paper. Cleveland, Ohio: Case Western Reserve University. http://weatherhead.case.edu/ degrees/doctor-management/research/details?id=12547\&topic=23. Accessed 7 July 2011.

Tsoi, J. (2010). Stakeholders' perceptions and future scenarios to improve corporate social responsibility in Hong Kong and Mainland China. Journal of Business Ethics, 91(3), 391-404.

UBS. (2009). Prices and earnings. Zurich: UBS AG, Wealth Management Research.

Von Tunzelmann, A., \& Cullwick, D. (1996). Social responsibility and the company: A new perspective on governance, strategy and the community. Wellington, New Zealand: Victoria University, Institute of Policy Studies.

Waddell, S. (2000). A "win-win" role for civil society in business strategy. Journal for Nonprofit Management, 4(1), 24-43.

Westwood, R. I., \& Posner, B. Z. (1997). Managerial values across cultures: Australia, Hong Kong and the United States. Asia Pacific Journal of Management, 14(1), 31-66.

Wiggins, J. S. (1991). Agency and communion as conceptual coordinates for the understanding and measurement of interpersonal behavior. In W. M. Grove \& D. Ciccetti (Eds.), Thinking clearly about psychology: vol. 2, Personality and psychopathology (Vol. 2, pp. 89-113). Minneapolis: University of Minnesota Press.

Wilson, J. (2000). Volunteering. Annual Review of Sociology, 26, 215-240.

Wong, A. L. Y. (2002). A study of managerial development in Taiwan. Unpublished doctoral dissertation. Birmingham, UK: University of Birmingham.

Wong, A. L. Y. (2007). Making career choice: A study of Chinese managers. Human Relations, 60(8), 1211-1233.

Wong, C. K. (2008). Squaring the welfare circle in Hong Kong: Lessons for governance in social policy. Asian Survey, 48(2), 323-342. 
Wong, K. Y., \& Wan, P. S. (2009). New evidence of the postmaterialist shift: The experience of Hong Kong. Social Indicators Research, 92(3), 497-515.

Yamamoto, T. (1999). Corporate-NGO partnership: Learning from case studies. In T. Yamamoto \& K. G. Ashikawa (Eds.), Corporate-NGO partnership in Asia-Pacific (pp. 13-38). Tokyo: Japan Center for International Exchange. http://www.jcie.org/researchpdfs/CorpNGOPart/ngo_yamamoto.pdf. Accessed 15 July 2011.

Yim, R. C. M. (2008). The management challenges facing social enterprises. Hong Kong Journal, 9, 5. http://www.hkjournal.org/archive/2008_spring/6.htm. Accessed 15 July 2011.

Yotsumoto, Y. (2002). Corporate social responsibility of Japanese manufacturing companies in a Kentucky community: A case study. Unpublished doctoral dissertation. Lexington, KY: University of Kentucky.

Yotsumoto, Y. (2010). Americanizing Japanese firms: The institutionalization of corporate philanthropy and volunteerism in American communities. Lanham: University Press of America. 